\title{
Conceptions of the professionals about their attributions in the Expanded Nucleus of Family Health
}

\author{
Meyrielle Belotti ${ }^{\top}$ \\ Alexandra Iglesias ${ }^{\top}$ \\ Luziane Zacché Avellar
}

${ }^{1}$ Universidade Federal do Espírito Santo, Vitória, ES

\begin{abstract}
The article aims to analyze the conceptions conferred by the health professionals that compose the Expanded Nuclei of Family Health (NASF) on their work assignments. This is a qualitative research, in which was used, for the data collection, eight focus groups, with a total of 43 participants. The data were submitted to content analysis. The results outlined the following categories: integrating NASF work with the Family Health Teams (ESF); developing specialized care; promoting intersectionality; contributing to the promotion of teamwork in Primary Care (AB) and strengthening AB. The study indicates the importance of a better understanding of the functions of the NASF, so that it does not restrict the opportunity to perform specialized care in AB. It is pointed out, the need for adjustments in the work processes of the ESF, in order to enable the shared work in the AB. keywords: single health system; focus group; primary health care.
\end{abstract}

Concepções dos Profissionais sobre suas Atribuições no Núcleo Ampliado de Saúde da Família

\begin{abstract}
Resumo
O artigo tem como objetivo analisar as concepções conferidas pelos profissionais de saúde que compõem os Núcleos Ampliados de Saúde da Família (NASF) sobre suas atribuições de trabalho. Trata-se de uma pesquisa de abordagem qualitativa, a qual se utilizou, para a coleta de dados, de oito grupos focais, com o total de 43 participantes. Os dados foram submetidos à análise de conteúdo. Os resultados delinearam as seguintes categorias: integrar o trabalho do NASF com as Equipes Saúde da Família (ESF); desenvolver um cuidado especializado; promover a intersetorialidade; contribuir para a promoção do trabalho em equipe na Atenção Básica (AB) e fortalecer a AB. O estudo indica a importância de compreender melhor as atribuições do NASF, para que este não se restrinja a oportunidade de realização do cuidado especializado na AB. Aponta-se, a necessidade de adequações nos processos de trabalhos das ESF, a fim de possibilitar o trabalho compartilhado na AB.

Palavras-chave: sistema único de saúde, grupo focal, atenção primária à saúde
\end{abstract}

Concepciones de los profesionales sobre sus atribuciones en el Núcleo Ampliado de Salud de la Familia

\begin{abstract}
Resumen
Este artículo tiene como objetivo analizar las concepciones conferidas por los profesionales de salud que componen los Núcleos Ampliados de Salud Familiar (NASF), sobre sus atribuciones de trabajo. Se trata de un enfoque cualitativo de investigación, utilizándose para la recolección de datos, ocho grupos focales, con un total de 43 participantes. Los datos fueron sometidos a análisis de contenido y los resultados resumen las siguientes categorías: integrar el trabajo del NASF con los Equipos de Salud Familiar (ESF); desarrollar un cuidado especializado; promover la intersectorialidad; contribuir para la promoción de trabajo en equipo en la Atención Básica (AB) y fortalecer la AB. Este estudio señala la importancia de comprender mejor las atribuciones del NASF, para que éste no se limite sólo a la oportunidad de realización de cuidado especializado en la AB. Se señala, la necesidad de ajustes en los procesos de trabajo de las ESF, con el fin de permitir el trabajo compartido en la AB.

Palabras clave: Sistema Único de Salud; grupo focal; atención primaria de salud
\end{abstract}

\section{Introduction}

The Family Health Team (ESF) is a proposal of reorganization and strengthening of Primary Care $(A B)$, through qualification, broadening of access and reorienting health practices. In order to promote full care, as well as to broaden the scope of the actions developed by the ESF in 2008, the Ministry of Health issued Ordinance no. 154, which establishes the Family Health Support Center, now called the Expanded
Nucleus of Family Health (NASF). According to the aforementioned decree, NASF can be composed of 19 professional categories, which include: psychiatrist, nutritionist, speech therapist, physical therapist, occupational therapist, psychologist, social worker, physical educator, among others, defined according to the needs of the territory (Brazil, 2014).

NASF is not a gateway to the health system, its actions are delimited to the demands of the territory, as identified in the joint work between the supported 
teams. Being so, its work process should be constituted by integrating not only with the ESF, but also with the $A B$ teams for specific populations (street offices, riverside populations and river teams) (Brazil, 2012). Sharing the actions/situations found in the territories is key to improving health care at $\mathrm{AB}$ level, as well as the activating communication spaces and joint deliberation. In order to exchange knowledge and practices and organizing the types of care in the attention networks, we must end the bureaucratization present in referencing and counter-referencing (Oliveira \& Campos, 2015).

To this end, the NASF uses matrix support as its working methodology, which aims to provide specialized back-up to the ESF, combining elements of clinical-assistive and technical-pedagogical character, which are often intertwined. The technical-pedagogical dimension comprises the exchange of knowledges and experiences between the teams when, for example, discussing a specific case or a theoretical question of common interest and needs. On the other hand, the clinical-assistive dimension requires that the supporter perform clinical actions directly with the users. However, it is recommended that this action be performed only in clinical situations of greater complexity (according to risk, vulnerability and severity), after agreement between the teams involved in the care, prioritizing joint care (between supporter and professional team of the supported) (Campos \& Domitti, 2007; Brazil, 2010, 2014).

In this context, it is indicated that the NASF teams also use transversal work tools, that is, those not of specific use to a certain professional category. Namely: the expanded clinic; the Singular Therapeutic Project (STP); and the Territorial Health Project (THP) (Brazil, 2014). The expanded clinic offers care that avoids an approach that would favor only one matrix of disciplinary knowledge, recognizing the interests of the people in a less prescriptive and more negotiated practice (Campos, Figueiredo, Pereira Júnior, \& Castro, 2014). The STP is a care strategy that brings together a set of proposals for an articulated therapeutic behaviors for a person, family or group, making use of the resources of both the team and the territory, the family and the subject itself (Pinto et al., 2011). Finally, the THP is a work tool that aims to develop effective actions to produce care in a territory, articulating health services with other services and social policies, so as to invest in the quality of life and autonomy of the communities (Brazil, 2010).
It should be noted that NASF has two target audiences in its work process. One of them is made up of teams, which offer support through the analysis of health problems and needs, to elaborate proposals for joint interventions. The other is the population that inhabits the territory, developing and individual or collective clinical actions are developed with users and their families when necessary, in an integrated and co-responsible manner with the professionals of other teams (Brazil, 2014).

The responsibilities attributed to NASF professionals are numerous and complex, varying between the definition of a work agenda that privileges pedagogical and assistive activities and the development of direct and shared actions with the ESF in the territory of its responsibility. Actions that can be developed by the NASF include: treatment with or without the ESF, discussing cases, elaborating STP and THP, discussing prevailing themes, strategy analysis for dealing with repressed demands, analyzing referencing, capacitation, interventions in the territory and in the health of population groups and the collective, cross sectorial practices, discussion of the work process of the teams, actions for promoting health and preventing diseases, among others (Shimizu \& Fragelli, 2014; Brasil, 2010; 2014).

We should also highlight the role of the NASF in the dialogue with the other points of attention of the Health Care Networks (RAS), which are organizational arrangements for health actions and services of different levels of complexity, integrated through systems of technical, logistic and managerial support, in order to guarantee integral care (Brazil, 2012). Thus, the NASF, in addition to developing a shared work with the $A B$ teams, must act in an integrated manner with the RAS and with the other social and community sectors in the territory, favoring inter-sectorial articulation. (Brazil, 2014, Sousa, Albuquerque, Nascimento, Albuquerque \& Lira, 2017).

It is important to emphasize that NASF is not unrelated to $\mathrm{AB}$. It composes the basic care, so its actions must contemplate the practices developed at this level of complexity. In other words, the NASF, along with other $\mathrm{AB}$ teams, should promote health education actions for the population; social participation to build participatory management; the permanent education in health, aiming at the transformation of professional practices and work organization and humanization, based on collective constructions 
between managers, workers and users (Brazil, 2010, 2014 and Sundfeld, 2010).

It should be noted that the NASF is still very recent and pioneering in Brazil. Its methodology of work organization in health is innovative and is in the process of being systemized. That being said, the NASF has been facing several challenges to consolidate its work, since there is still a predominant culture of practices guided by the biomedical model, which favors the fragmentation of care and specialisms, to the detriment of interdisciplinary and collaborative work. Moreover, the NASF faces another challenge, in view of the new National Policy on Basic Attention (PNAB), on 2017, regarding, for example, the construction of bonds and continuous care, attributes conquered by a comprehensive $\mathrm{AB}$ proposal. That is, considering that the PNAB 2017 proposes the creation of teams with partial dedication to $\mathrm{AB}$ and relativizes the population coverage to health services, restricted to certain areas of risk and vulnerability (Brazil, 2017, Morosi, Fonseca \& Lima, 2018).

In this sense, the bet is that it will be based on the day-to-day experience of the already established NASF teams, that the importance of this integration between the $A B$ teams will be affirmed, for a more effective care to the population, leading to changes in the policies and in the practice. In this article, the objective is to understand the conceptions of the NASF health professionals on their work assignments, understanding whether these conceptions materialize in practices more or less favorable to the consolidation of $\mathrm{AB}$ in its principles of universality, accessibility and coordination of care, bonding (user-team), continuity, completeness, accountability, humanization, equity and social participation (Brazil, 2012). And the psychologist, being part of the NASF team, makes it important that such discussion is appropriated, and contribute to the debates about receptivity and contextualized listening, for example, that are in their core knowledge, to compose the field of action of other $\mathrm{AB}$ professionals, favoring the strengthening of this level of attention.

\section{Method}

\section{Type of study}

This is a qualitative research, with the purpose of understanding the meanings, senses, intentionalities and subjective issues inherent in acts, attitudes, relationships and social structures (Minayo, 2008). Based on the proposal to understand the conceptions conferred by health professionals that compose the NASF on their work assignments, the qualitative method proved to be the most adequate.

\section{Research Participants}

Eight NASF teams from a municipality in the Southeast Region of Brazil participated in the study, corresponding to the total number of teams registered in said municipality. The teams were composed of psychologists, social workers, speech therapists, physical educators and pharmacists. Each group had an approximate number of five to six participants, 43 professionals in total, from the following categories: 11 psychologists, 13 social workers, five speech therapists, nine pharmacists and five physical educators.

\section{Collection procedures}

For the data collection, we used the focus group technique, which aims at the interaction between the participants and the researcher, through a discussion focused on previously defined topics (Silva, Veloso \& Keating, 2014). The triggering topic of the discussion was the professionals' conceptions about their NASF attributions, and this was the only resource used to encourage reflections on the issue addressed. We sought to create a favorable environment so that different perceptions and points of view on the theme came to light. To facilitate the interaction of the participants, the chairs were set up in a circle. In all sessions they were assured of their right to privacy.

With regard to the operationalization of the focus groups in this research, each session had one researcher coordinating and another observing. The attributions of the coordinator were: to clarify the dynamics of the focus groups; explain the ethical aspects linked to the research; facilitate the discussion; stimulate the debate. The observer was in charge of registering the group dynamics, assisting in conducting the discussions, collaborating with the coordinator in controlling the time and monitoring the recording equipment.

The focus groups were held in March and April 2016. Eight focus group sessions were held. We had a focus group session with each NASF team in the municipality. The groups had an average duration of approximately one and a half hours. All focus groups were recorded and transcribed later. It is worth mentioning that this research was approved by the Research Ethics Committee of the Federal University of Espírito Santo (UFES) (no. 47881815.7.0000.5542) and by the Municipal Health Department. All the participants 
signed a Free and Informed Consent Form (FICF), in compliance with Resolution 466/12 of the National Health Council.

\section{Data analysis}

We used the content analysis technique, as proposed by Bardin (2011), with the following steps: (1) pre-analysis, (2) exploration of the material and (3) treating results. The pre-analysis of the data was constituted by a floating reading of the transcription of the focus groups, cutting excerpts of the speech that contemplated the objective of the study. Then we categorized the data, organizing based on the meaning and significance conferred by NASF health professionals to their attributions. Finally we set up the data processing, which culminated in the reflexive analysis of the data, using the five categories constructed after the transformation of the raw data, in the material exploration phase, as guiding elements. To present each category, excerpts of the participants' speeches were separated, identified by professional category, accompanied by the letter $\mathrm{S}$, followed by a number, representing the focus group session (psychologist S.1, social worker S.2, physical educator S.3, etc.).

\section{Results and discussion}

According to the analysis process detailed earlier, the NASF professionals' conceptions of their work assignments outlined five categories: (1) integrate the work of the NASF with the ESF; (2) develop specialized care; (3) promote intersectionality; (4) contribute to the promotion of teamwork in $\mathrm{AB}$ and (5) strengthen $\mathrm{AB}$. We opted for a joint discussion with the presentation of the results.

\section{Integrating NASF work with ESF}

This category incorporates statements regarding the participants' understanding of the NASF's assignment of acting with ESF. With regard to these attributions, the following actions were described: increasing the resoluteness of $\mathrm{AB}$, avoiding referrals to other points of attention; promoting case discussions aiming to improving the work of the ESF and improving the offer of services in the territory; supporting and sharing care.

"The NASF was born to increase the resoluteness of the care and the effectiveness of the care with the ESF, so that not all users have to be referred to specialists or to another point of attention" (pharmacist S.05).
"It is a group of professionals who meet to discuss cases and improve ESF, to offer the best service to that community in which we are" (psychologist S.06).

"To me, the NASF is what the name already speaks, a support in Family Health. So the NASF is born to share the care with these teams, which work together with the ESF" (social worker S.05).

These speeches agree with several studies on the NASF (Silva et al., 2012; Santana, Azevedo, Reichert, Medeiros \& Soares, 2015; Patrocínio, Machado \& Fausto, 2015) that point out that the organization of NASF work processes should prioritize the shared work and case discussion, to increase $\mathrm{AB}$ level of resoluteness, avoiding unnecessary referrals to other points of attention on the RAS. Therefore the NASF must be configured as a support team, acting with the ESF and integrating them to favor a broad attention as well as the resoluteness and quality of care for the population in their territory.

Although the data point to statements coherent with what are the NASF assignments with ESF in theory, it is important to point out that operationalizing the integrated work between these teams (NASF and ESF) has been facing several challenges still to be overcome. Among these, we mention: the difficulty in promoting co-responsibility of care; construction of teamwork in the interdisciplinary perspective, without losing the the specific characteristics; guaranteeing collective spaces for the discussion of cases and for planning the shared work; the role of the NASF in the training of the $\mathrm{AB}$ health professional, among others (Ferro, Silva, Zimmermann, Castanharo \& Oliveira, 2014; Silva et al., 2012). In view of these challenges, we must emphasize the importance of enabling routine spaces between the NASF and the ESF, governed by the methodology of matrices, thus favoring the joint elaboration of actions, the exchange of knowledge and the resoluteness of care.

As we have previously mentioned, the matrix support must allow that the integration between NASF and ESF teams be configured in different ways, combining clinical-assistential elements with technical-pedagogical elements according to the needs from each territory, as well as the demands that come from ESF. Even though there are several possibilities of integration between the teams (NASF and ESF), the data shows that the participants in the research have difficulty in performing attention care integrated between NASF and ESF, with the NASF professionals being the only professional in most practices. 
"We have been doing home visits, through the demands of the Community Health Agents and meetings with the Famiby Health teams. Some shared care, NASF with NASF" (speech therapist S.02).

"T already did it with the nurse, but it is very rare that this happens" (social worker S.02).

"There are cases of shared care, which is not always, to schedule is one thing" (psychologist S.07).

Although the shared work is a directive that guides the actions of the NASF, several studies (Barros, Gonçalves, Kalther \& Lancman, 2015; Ribeiro, et al., 2015; Silva, et al., 2012; Lancman, Gonçalves, Cordone \& Barros, 2013) point to different factors that make the shared work hard to accomplish among professionals from the Nucleus and the ESF, namely: the resistance of professionals in the ESF and in the NASF to agree in joint actions; the diverse conceptions that each professional has of their own practices; the power relations between professional categories and the different ways of organizing work and the aspects related to productivity. Specifically, on this latter item, Lancman et al. (2013) points out that there is a great demand for care directed to the ESF that, in general, demand quick and urgent solutions. In contrast, the work of the NASF prioritizes discussion, reflection and shared action, demanding availability and time for all involved. This produces a mismatch between the need to meet the demand and the new work logic proposed by the NASF, which interferes directly with the work pace of the teams, the relationships, the time allocated for sharing and the resolution of cases, among other aspects.

\section{Developing specialized care}

The speeches that described NASF's work as a specialized care were grouped into this category. In the reports we verify that the work of the NASF is characterized as a specialized attention, in which some professionals are titled as specialists inserted in the AB. In addition, the data also reveal the NASF staff's perception of what the ESF expected from their work. According to the NASF professionals, there was an expectation from the ESF that the professionals of the Nucleus would present solutions to the health problems experienced in the daily life of the service.

"We are specialists, but of primary care" (social worker S.05).
"I think there is another problem with the matrix proposal, which is the idea that we act as specialists" (speech therapist S.02).

"(...) we are being put in a higher position, that of supposed knowledge. Now you, because NASF knows what to do. Do you have to deal with it? We meet the strategy professionals in the corridors and they ask us: what did the NASF solve? They expect solutions from us to problems that come to the unit" (psychologist S. 06).

It is worth remembering that the proposal of matrix support is to ensure specialized support to the teams and professionals in charge of health care. Therefore, a specialist with a certain type of knowledge, supports professionals with another training, to increase the effectiveness of their performance. In this proposal, there is no hierarchy between the professionals and no overvaluation of the specialists' knowledge. We seek to create a relation of complementing the knowledge (Cunha \& Campos, 2011).

That said, we must be careful and ensure that the specialized backup is not confused as a specialized care, governed by the subordination of the ESF to the NASF teams, or by the expectation that the NASF will present ready solutions to the health problems that exist in the territory. In other words, the professional of the Nucleus takes on the role of "specialist" in its role of supporter, to increase the resolution of $\mathrm{AB}$ and avoid unnecessary referrals to the other levels of complexity, fulfilling one of their attributions of the NASF. This misunderstanding may favor the organization of NASF's work as a specialized service in AB.

The data also point out that the inexistence, or frailty, of the RAS enhances the development of specialized actions by NASF teams. The speeches also show that some participants in the research have the understanding that NASF teams will require the construction of a network in order to avoid NASF teams from working as specialists in $\mathrm{AB}$.

\footnotetext{
"If there are patients who need this type of care, you have to deal with it as well. So how do we balance this, if we do not have specialized centers to address this demand, nor a network that accommodates this. Who will attend to these cases?" (speech therapist S.08).

"The NASF will require that we think about the work process of the municipality, because I need to have where to refer a person who has sequels of a stroke, or will I keep them in basic care? I don't know how this process is in management. If this is being thought of, but here we can glimpse that it is necessary to have a network" (speech therapist S.07).
} 
This corroborates with Cunha and Campos (2011) that the absence of an articulated network which contemplates specialized services may favor a mistaken functioning of the NASF which in turn assumes a role of replacing the missing services in an attempt to meet the demand of population. Giovanella (2014) collaborates with this discussion, emphasizing that the accomplishment of work in $A B$, consistent with its proposal, is conditional on the adequate availability of services that also make up the specialized attention. The author also points out that, despite the fact that investments in specialized healthcare in the SUS (Sistema Único de Saúde - Unified Health System) have taken place in recent years, there is the need to approve a national policy of specialized regional attention, to expand the offer of specialized services and, consequently, the condition of work in $\mathrm{AB}$.

However, it should be noted that, in addition to an adequate supply of specialized services, it is necessary for $A B$ to be clear about its responsibilities and possibilities of care, so that the specialists aren't over-evaluated. In addition, it should be noted that $\mathrm{AB}$ also has attributions to the demands of rehabilitation. However, as highlighted in Administrative Order $2,488 / 2011$, this care must be developed in a coordinated manner with the other services that make up the RAS, and it is the responsibility of the ESF, together with NASF, to promote this integration, optimizing care (Brazil, 2012).

\section{Promoting intersectionality}

This category incorporates the statements related to the work of NASF articulated with other sectors. According to some professionals, the NASF teams develop actions of intersectoral character with the services of the different sectors of the territory, being characterized as an integrated work network, systematized through monthly meetings, for the discussion of cases, exchange of ideas, debates and plans of actions.

"... we seek to work integrated with the part of the assistance, of the city hall, CREAS and CRAS" (social worker S.03).

'There's the network meeting. Where once a month diverse sectors of the community gather for the exchange of ideas, debates, subjects" (psychologist S.08).

"We have a meeting once a month with CREAS, CRAS, the schools, the tutelary councils, with all the equipment of the territory. There are the case discussions and the planning of some actions" (social worker S.04).
We can see that the conceptions about intersectionality present in the above statements, together with the understanding pointed out by Paula, Palha and Protti (2004) emphasize the intersectionality as interrelations of work processes articulated among themselves, which acquire a broad character, based on partnerships with other institutions in the network. Thus, the intersectional practices establish connections between different services, in order to catalyze a network that understands the health and disease process in an expanded way, through problematization and articulation of different knowledge, in search for joint solutions to the needs of each territory. However, although some NASF professionals understand the intersectionality as a network action, it was also possible to identify statements that illustrate that this practice, in certain moments, occurs in a specific way and only in complex cases/situations.

"Intersectional, unless the child has a more deviant behavior
in school, then the school calls us to talk" (psychologist S.02).
"But the intersectional discussions are due to a complex case,
if there is any case to discuss. It's for discussing cases. This is
how it works" (physical educator S.22).

Apparently, concrete and complex situations have mobilized more people and services to create spaces for articulation. However, working intersectionally involves integrating collective agendas with common goals, to produce impacts on the life quality of the community (Amaral, 2015). Thus, intersectional actions can not be just for specific situations. Its proposal presupposes a constant dialogue between the sectors in the territory, in an attempt to break the isolated and vertical cycles in the public policies, to guarantee the fundamental rights of the population.

The data also point to some conceptual misconceptions about intersectionality. Among these, we highlight the understanding of intersectionality as a referral to other sectors and as partnership with some institutions of the territory for informative and thematic workshops/lectures.

"I understand as a referral and as workshops as well. Like the ones we do at school" (social worker S.06).

"We do some actions with companies, there are two companies here, in the territory, garbage companies, they always call us for some activity. They call and ask, can you do an activity to talk about men's health? Basic things, really basic, are specific actions like lectures, but that demand an interaction of the team with the company" (psychologist S.06).

Psico-USF, Bragança Paulista, v. 24, n. 4, p. 661-671, out./ dez. 2019 
Analyzing these statements shows the insipidity of joint planning among the professionals of the different sectors, in order to face the complex problems that exist in the territory. The relationship established with other equipments is restricted to referrals and the presentation of an informative lecture. Thus, the intersectionality associated with these conceptions reveals a multisectorial practice, characterized by the presence of two or more sectors to solve a problem, but with no reciprocity or partnership, nor an effective sharing of something or of a process (Ornelas \& Teixeira, 2015). Finally, there are also reports that associate the idea of intersectional practice with the relationship built with some specialized services in the field of health, that is, as an articulation between the RAS services, without the presence of the other social and community policies.

"There are intersectional actions with SAVI, with CAPS,
in general (..). SAVI is a service of care for victims of
violence. It's in the network. From the same office as ours"
(social worker S.04).

Although this articulation with the network of specialized services is of fundamental importance for the achievement of integrality, such action cannot be characterized as an intersectional practice. This reveals the difficulty that the professionals have of working together with other social policies, which in consequence favors the fragmentation of care and the activation of other sectors through the logic of referral.

\section{Contributing to the promotion of teamwork in $A B$}

The statements related to the relations established between the disciplines and teamwork were grouped in this category. We observed that some participants have theoretical clarity about the competence of the NASF in providing the integration of knowledge, attenuating the limits imposed by the disciplines.

'I think, now that I'm a part of NASF, we need to team up to discuss further certain informations from each professional" (Pharmacist S.04).

"I think the logical thing is for us to start making more reflections with the team, strengthening the team even with information that is from my domain, sharing knowledge" (psychologist S.06).

Exchanging information from "my domain" means sharing with the others my core knowledge in order to broaden the common field of practice between disciplines. That is, it is an extension of the field of knowledge from the intersection of knowledges, skills and methods of each professional category, in order to respond adequately to the health needs of the territory. In this proposal, the knowledge centers are constituted by the agglutination of knowledge of a certain professional category, outlining the specificity of an area of knowledge and professional practice. The field of knowledge is a space of intersection between knowledge, imprecise limits, socialization of knowledge and practices among the various professionals, thus increasing the capacity for care among those involved (Campos et al., 2014).

It should be emphasized that the construction of this expanded field of knowledge does not imply abandoning the core knowledge of the disciplines, since it can enrich the common field of competence, thus increasing the capacity of care of the entire team (Oliveira \& Campos, 2015). Therefore, Nucleus and field must "walk hand in hand", as reported in the following speech.

\begin{abstract}
"We are afraid, of where this core knowledge story is going, it cannot be so ironclad. It is a double-edged sword, it can go in the opposite direction because you expropriate the core of a professional's knowledge to the detriment of the field. The theory is very beautiful, you take ownership of the field of knowledge. Of course, it is something that we need and must do, but not to the detriment of the other. The two things go together" (psychologist S.06).
\end{abstract}

Oliveira and Campos (2015) emphasize that both the knowledge base and the field of knowledge are mutant and influence each other, it is not possible to detect precise limits between one and the other, nor to discard the presence of the Nucleus. In other words, there is no polarity or antagonism between these two concepts. The notion of core indicates a certain concentration of knowledge, but in no way indicates a radical break with the dynamics of the field.

The professional performance in the field has as a consequence the reduction of the disciplinary boundaries, since each profession seeks support in other areas to meet the daily demands of work. Although some professionals perceive the importance of sharing their core knowledge, some reports reveal difficulty in organizing meetings guided by interdisciplinarity.

\footnotetext{
"... This is very new. It's a new logic for us. Because sometimes it is easier to take that case and conduct it alone than having to share it with the team" (speech therapist S.06).
} 
It is notable that there is still a great desire for ambulatory logic, guided by fragmented and specialized procedures, as opposed to the "new logic", which refers to collaborative teamwork, with shared decisions, encouraging the exchange of knowledge, co-responsibility for care and the mainstreaming of relations. Thus, conducting a "solo" job seems to be an easier path since health professionals tend to want to deal only with the problems related to their core of knowledge, with the opinions expressed about their conduct being seen as inopportune and invasive. This reality reveals the difficulty of giving and receiving critiques, dealing with novelty and with shared decision-making (Silva et al., 2012).

That being said, it is necessary to expand the knowledge about collaborative processes in $\mathrm{AB}$, recognizing its potential contribution to reach integral care. In addition, it should be clear that interprofessional collaboration is not only an individual and personal effort of the health professional, but also a collective and extended effort of several agents (professionals, managers and users) for effective integration (Matuda, Pinto, Martins \& Frazão, 2015).

\section{Strengthening $A B$}

The issues related to the consolidation of the $\mathrm{AB}$ proposal through the creation of the NASF also emerged in the statements presented. As illustrated in these statements, professionals identify the rescue and strengthening of $\mathrm{AB}$ as one of NASF's tasks, extending care beyond the practices based on the biomedical model. The statements are still about the strengthening the SUS, through NASF's support of AB.

\footnotetext{
"NASF is primary care, it is within this proposal, but I think the main treasure is the rescue of basic care. Thinking, in this perspective, is not only a matter of treatment and illness" (physical educator S.06).

"... we have to boost and bring back the initial proposal of primary care, to empower the ESF itself that is under the risk of promoting individualistic medical practices" (psychologist S.04).

"We still do not support SUS in Primary Care. So, I see the $N A S F$ a lot in this sense, to be a trigger to strengthen the Primary Care" (social worker S.05).
}

In agreement with Oliveira and Quevedo (2016) who state that the structure of NASF's work must be guided by the expansion and improvement of the work in the $\mathrm{AB}$, promoting integral care in an attempt to break actions that are merely centered on the disease. However, it should be emphasized that strengthening $A B$ is not exclusive to the Nucleus professionals. It is known that ESF were implemented in order to overcome the problems at this level of complexity, promoting the improvement of care and restructuring the healthcare model. In turn, the NASF emerges as a device that enhances the actions of the ESF. Therefore, the work of both teams - NASF and ESF - should be guided by common goals that seek to foster changes in $\mathrm{AB}$ actions.

The task of strengthening $\mathrm{AB}$ falling only to the professionals of the Nucleus, has caused some concerns to the participants of the research, since there are several factors and challenges around this question. The following statement demonstrates the perception that there are some challenges that need to be addressed in order to consolidate the proposed $\mathrm{AB}$, which aren't exclusive to the NASF, such as: institutional issues; the management; the processes of teamwork and the cultural question itself that pervades health care.

"We are frightened by the size of this responsibility, because there are many things there that are not just NASF. There are some institutional issues that need to happen. So, I think it's a very heavy load that's being required from the NASF. There is also a cultural issue and the management issue that need to be addressed. There is also the question of the work processes of the teams that are not being discussed anymore. So, we will be the ones that come to the rescue. This is very complicated" (social worker S.06).

It appears that the "old challenges" of $\mathrm{AB}$ seem to be understood by some as "new challenges" to the NASF. This goes in agreement with Savassi (2012), pointing out that, in order to overcome these challenges, it is essential to carry out a change that is both managerial and organizational, to promote the change from a focus on disease and healing, to a focus on health promotion and teamwork. In this process of change, the NASF must be understood as another device that can aid in confronting his scenario. Thus, the Nucleus professionals should join forces with the other teams that work at this level of complexity, and the expectation that the NASF "come to the rescue" should not be created.

\section{Final considerations}

This article had as objective the analysis of the conceptions that the health professionals who 
compose the NASF have of their work assignments. The results indicate that their conceptions revolve around some theoretical understandings already brought by the policies: to support the ESF, aiming to increase the resoluteness of the care in the $\mathrm{AB}$; promote intersectionality; foster interdisciplinarity and strengthen work in $\mathrm{AB}$, rupturing with certain biomedical practices.

There is also a category that grants the part of specialist in AB to the Nucleus professionals. Both ESF and in NASF must be clear on what the functions of a specialist are, which were conferred to the NASF specialists through the matrix, so that this attribution is not mistaken for a secondary attention given in AB. Furthermore, the scarcity of specialized services and of an articulate RAS were also identified as factors that favor the development of specialized care at NASF.

Another aspect that deserves to be highlighted is the shared and interdisciplinary teamwork. Although the research participants understand the importance of knowledge exchange, there is difficulty to operationalize this practice, due to the dominance of fragmented practices and specialties. Faced with this reality, we believe that matrix support can be a resource used to contribute to collaborative work, establishing a dialogical and democratic interprofessional relationship, thus replacing the traditional bureaucratic and hierarchical relationships that still exist in the field of health.

We also consider that the difficulties of the shared work between ESF and NASF are also related to ministerial regulations. The actions of the ESF are strongly focused on productivity goals, while NASF regulations allow for greater flexibility in the composition of the actions carried out. In this scenario, the discrepancies of work between the NASF and the ESF, and assuming that the shared work requires, mainly, availability for meetings with one another, we see the need to make changes in the organization of the work of the ESF, to favor the accomplishment of work shared between these teams (ESF and NASF).

This study indicates that the construction of a theoretical framework to support the concept of intersectionality is pertinent, since it was possible to identify different conceptions about the practice. Thus, depending on the conception to which it is linked, intersectionality can be configured as a punctual strategy, or as a multisectoral action. We also point out, the need to create mechanisms that enhance the articulation of the points of attention of the RASs, in order to favor the co-responsibility of all levels of attention over the care for the population, thus establishing a new logic of organization of the health services.

With the results of this research, it is understood that the NASF can be an innovative device, capable of producing impacts on traditional health practices, by means of prioritizing interdisciplinarity and integral care. It is believed that this research may favor the discussions related to conceptions about NASF and its methodology of work, in order to trigger new work processes in health, as well as to promote the improvement of policies directed at AB. It is important to note that one of the limitations of this study is due to the fact that data collection was performed during the implementation process of the NASF teams monitored in this study, meaning that the focus groups were held at a time when the practitioners were appropriating their work in the NASF. In addition, it is necessary to carry out other researches that focus on the observation of practices to understand how the concepts effectively materialize in the daily work.

\section{References}

Amaral, L.M. (2015). A intersetorialidade na gestão de políticas sociais: o contexto da produção científica brasileira (Dissertação de mestrado). Programa de pós-graduação em terapia ocupacional da Universidade Federal de São Carlos, São Carlos, Brasil.

Bardin, L. (2011). Análise de conteúdo. Lisboa: Edições 70.

Barros, J.O., Gonçalves, R.M.A., Kaltner, R.P., \& Lancman, S. (2015). Estratégia do apoio matricial: a experiência de duas equipes do Núcleo de Apoio à Saúde da Família (NASF) da cidade de São Paulo, Brasil. Ciência \& Saúde Coletiva, 20(9), 2847-2856. doi: 10.1590/1413-81232015209.12232014

Brasil. (2010). Diretrizes do NASF: Núcleo de Apoio a Saúde da Família. Brasília: Ministério da Saúde.

Brasil. (2012). Politica Nacional de Atenção Básica. Brasilia: Ministério da Saúde.

Brasil. (2014). Núcleo de Apoio à Saúde da Família (Cadernos de Atenção Básica, n. 39). Brasília: Ministério da Saúde.

Brasil. (2017). Portaria no 2.436, de 21 de setembro de 2017. Brasília, DF: Ministério da Saúde.

Campos, G.W.S., \& Domitti, A.C. (2007). Apoio matricial e equipe de referência: uma metodologia 
para gestão do trabalho interdisciplinar em saúde. Cad. Saúde Pública, 23(2), 399-407. doi:10.1590/ S0102-311X2007000200016.

Campos, G.W.S, Figueiredo, M.D., Pereira Junior, N., \& Castro, C.P. (2014). A aplicação da metodologia paideia no apoio institucional, no apoio matricial e na clínica ampliada. Interface (botucatu), 18(1), 983995. doi:10.1590/1807-57622013.0324.

Cunha, G.T., \& Campos, G.W.S. (2011). Apoio matricial e Atenção Primária em Saúde. Saúde Soc, 20(4), 961-70. doi:10.1590/S0104-12902011000400013

Ferro, L.F., Silva, E.C., Zimmermann, A.B., Castanharo, R.C.T., \& Oliveira, F.R.L. (2014). Interdisciplinaridade e intersetorialidade na Estratégia Saúde da Família e no Núcleo de Apoio à Saúde da Família: potencialidades e desafios. O Mundo da Saúde, 38(2), 129-138. Retrieved from: https://www.saocamilo -sp.br/pdf/mundo_saude/155562/A01.pdf

Giovanella, L. (2014). Atenção Primária à Saúde e coordenação dos cuidados na rede assistencial. Divulgação em Saúde para Debate, 51, 30-37. doi: 10.1590/1413-81232017224.28632016

Lancman, S., Gonçalves, R.M.A., Cordone, N.G., \& Barros, J.O. (2013). Estudo do trabalho e do trabalhar no Núcleo de Apoio à Saúde da Família. Rev Saúde Pública. São Paulo, 7(5), 968-75. doi: 10.1590/ S0034-8910.2013047004770

Matuda, C.G., Pinto, N.R.S., Martins, C.L., \& Frazão, P. (2015). Colaboração interprofissional na Estratégia Saúde da Família: implicações para a produção do cuidado e a gestão do trabalho. Ciência \& Saúde Coletiva, 20(8), 2511-2521. doi:10.1590/1413-81232015208.11652014

Minayo, M.C.S. (2008). O desafio do conhecimento: pesquisa qualitativa em saúde. São Paulo: Hucitec.

Morosini, M.V.G.C., Fonseca, A.F., \& Lima, L.D. (2018). Política Nacional de Atenção Básica 2017: retrocessos e riscos para o Sistema Único de Saúde. Saúde Debate, 42(116), 11-24. doi: 10.1590/0103-1104201811601

Oliveira, F.R., \& Quevedo, M.P. (2016). Núcleo de Apoio a Saúde da Família (NASF) e a construção das Redes de Atenção à Saúde. Em Santos, M. L.M., Kodjaoglanian, V.L., \& Ferrari, F.P. (Eds.). O NASF em cena: tecnologias e ferramentas de trabalho no cotidiano das equipes (pp. 113-144). Porto Alegre: Rede Unida.
Oliveira, M.M., \& Campos, W.G.S. (2015). Apoios matricial e institucional: analisando suas construções. Ciência \& Saúde Coletiva, 20(1), 229-238. doi: 10.1590/1413-81232014201.21152013

Ornelas, A.L., \& Teixeira, M.G. (2015). Intersetorialidade ou diálogos setoriais? Reflexões a partir da experiência do Projeto Teias-Escola Manguinhos, Rio de Janeiro. Saúde em Debate [online], 39(106), 659670. doi: 10.1590/0103-110420151060003008.

Patrocínio, S.S.S.M., Machado, C.V., \& Fausto, M.C.R. (2015). Núcleo de Apoio à Saúde da Família: proposta nacional e implementação em municípios do Rio de Janeiro. Saúde Debate, 39(N. Especial), 105119. doi: 10.5935/0103-1104.2015S005373

Paula, K.A., Palha, P. F., \& Protti, S. T. (2004). Intersetorialidade: uma vivência prática ou um desafio a ser conquistado? O Discurso do Sujeito Coletivo dos enfermeiros nos Núcleos de Saúde da Família do Distrito Oeste - Ribeirão Preto. Interface - Comunic., Saúde, Educ., 8(15), 331-48. doi: 10.1590/ S1414-32832004000200011.

Pinto, D.M., Jorge, M.S.B., \& Pinto, A.G.A., Vasconcelos, M.G.F., Cavalcante, C.M., \& Flores A.Z.T. (2011). Projeto Terapêutico Singular na produção do cuidado integral: uma construção coletiva. Texto Contexto Enferm, 20(3), 493-302. doi: 10.1590/ S0104-07072011000300010

Ribeiro, H.M.C.B., Lamy, Z.C., Coimbra, L.C., Rocha, L. J.L.F., Aquino, D.M.C.C, Nair P. S., \& Costa, L.F.A. (2015). Representações sociais de profissionais dos Núcleos de Apoio à Saúde da Família sobre interdisciplinaridade. Trabalho, Educação e Saúde, 13(Suppl. 2), 97-115. doi: 10.1590/1981-7746-sip00082

Santana, J.S., Azevedo, T.L., Reichert, A.P.S, Medeiros, A.L., \& Soares, M.J.G.O. (2015). Núcleo de apoio à saúde da família: atuação da equipe junto à estratégia saúde da família. Rev. fundam. Care,7(2), 2362-2371. doi: 10.9789/2175-5361.2015.v7i2.2362-2371

Savassi, L.C.M. (2012). Qualidade em serviços públicos: os desafios da atenção primária. Rev bras med fam comunidade, 7(23): 69-74. doi: 10.5712/rbmfc7(23)392

Shimizu, H.E., \& Fragelli, O.T.B. (2016). Competências Profissionais Essenciais para $O$ Trabalho no Núcleo de Apoio à Saúde da Família. Revista Brasileira de Educação Médica, 40(2), 216-225. doi:10.1590/1981-52712015v40n2e02702014

Psico-USF, Bragança Paulista, v. 24, n. 4, p. 661-671, out./dez. 2019 
Silva'A.T.C., Aguiar, M.E.A., Winck, K.,Rodrigues, K. G.W., Sato, M.E., Grisi, S.J.F.E., Brentani, A., \& Rios, I.C. (2012). Núcleos de Apoio à Saúde da Família: desafios e potencialidades na visão dos profissionais da Atenção Primária do Município de São Paulo, Brasil. Cad. Saúde Pública, 28(11), 20762084. doi: 10.1590/S0102-311X2012001100007

Silva, I.S., Veloso, A. L. \& Keating, J. B. (2014). Focus group: Considerações teóricas e metodológicas. Rev. Lusófona de Educação [online], 26(1), 175190. Retrieved from: http://www.scielo.mec.pt/ pdf/rle/n26/n26a12.pdf
Sousa, F.O.F., Albuquerque, P.C., Nascimento, C.M.B., Albuquerque, L.C., \& Lira,

.C. (2017). O papel do Núcleo de Apoio à Saúde da Família na coordenação assistencial da Atenção Básica: limites e possibilidades. Saúde Debate, 41(115), 1075-1089. doi: 10.1590/0103-1104201711507

Sundfeld, A. (2010). Clínica ampliada na atenção básica e processos de subjetivação: relato de uma experiência. Physis: Revista de Saúde Coletiva, 20(4), 1079-1097, 2010. doi: 10.1590/S0103-73312010000400002

Recebido em: 02/06/2018

Reformulado em: $16 / 10 / 2018$

Aprovado em: 07/12/2018

About the authors:

Meyrielle Belotti. PhD student in Psychology at the Federal University of Espírito Santo (UFES). Master in Institutional Psychology at UFES. Holds a degree in Occupational Therapy from the São Pedro Integrated School. Assistant Professor at the Department of Occupational Therapy, UFES. Has experience in the field of collective health working mainly in the following subjects: mental health, basic care, matrix support, intersectoral and network.

ORCID: https://orcid.org/0000-0003-3901-4656

E-mail:meyri.belotti@gmail.com

Alexandra Iglesias. Graduated in Psychology at the Federal University of Espírito Santo (UFES). Master in collective health from the same University. PhD from the Post-Graduation Program in Psychology at UFES. Adjunct Professor, UFES / Department of Psychology. Has experience in the areas of collective health, mental health and health psychology, working mainly on the following topics: health promotion, matrix support, mental health and basic care.

ORCID: https://orcid.org/0000-0001-7188-9650

E-mail: leiglesias@gmail.com

Luziane Zacché Avellar. Holds a degree in Psychology from the Federal University of Espírito Santo (UFES), a Master's degree in Social Psychology from the Pontifical Catholic University (PUC) in São Paulo, and a PhD in Clinical Psychology from PUC in São Paulo. She is currently a Professor at UFES. Has experience in the area of Psychology, working mainly in the following subjects: health, mental health and children's mental health.

ORCID: https://orcid.org/0000-0003-3125-2174

E-mail: luzianeavellar@yahoo.com.br

Contact:

Universidade Federal do Espírito Santo - Programa de Pós-Graduação em Psicologia - Centro de Ciências Humanas e Naturais - Edifício Professor Lídio de Souza

Av. Fernando Ferrari, n 514 , Goiabeiras

Vitória-ES, Brasil

CEP: 29075-910

Psico-USF, Bragança Paulista, v. 24, n. 4, p. 661-671, out./ dez. 2019 